\title{
Absence of ras gene mutations in early gastric carcinomas
}

\author{
M E Craanen, P Blok, B Top, L Boerrigter, W Dekker, G J A Offerhaus, G N J Tytgat, \\ $S$ Rodenhuis
}

Departments of Gastroenterology and Pathology, Academic Medical Centre, Amsterdam, the Netherlands $M$ E Craanen G J A Offerhaus G N J Tytgat

Departments of Medical Oncology and Division of

Experimental

Therapy, The

Netherlands Cancer

Institute, Amsterdam,

the Netherlands

M E Craanen

B Top

L Boerrigter

$S$ Rodenhuis

Department of Pathology, Westeinde Ziekenhuis, the Hague, the Netherlands

P Blok

Department of

Internal Medicine,

Kennemer Gasthuis,

Haarlem, the

Netherlands

W Dekker

Correspondence to:

Dr M E Craanen,

Department of

Gastroenterology, Academic

Medical Centre,

Meibergdreef $9,1105 \mathrm{AZ}$

Amsterdam, the

Amsterdam,

Accepted for publication

21 April 1995

\begin{abstract}
The aims of this study were to assess the prevalence and type of activating point mutations at codons 12,13 , and 61 of the $\mathrm{Ki}-, \mathrm{Ha}-$, and $\mathrm{N}$-ras genes in a series of early gastric carcinomas in white patients and to correlate these ras gene mutations, if any, with the histological type (Lauren classification), the type of growth pattern, and with the Helicobacter pylori status. Haematoxylin and eosin and Giemsa stained sections from $\mathbf{4 5}$ formalin fixed, paraffin wax embedded early gastric carcinomas were used to assess the Lauren type, the type of growth pattern, and the antral $H$ pylori status. DNA was extracted according to standard procedures. Mutations at codon 12 of the Ki-ras gene were examined with a polymerase chain reaction based restriction fragment length polymorphism (PCR-RFLP) method and dot blot hybridisation with allele-specific ${ }^{32} \mathrm{P}$-labelled oligodeoxynucleotide (ASO) probes. All other ras genes were analysed with specific PCR amplification and dot blot hybridisation with ASO probes. Mutations were detected by overnight autoradiography at $-70^{\circ} \mathrm{C}$. Some 20 intestinal-type and 25 diffuse-type early gastric carcinomas were seen. According to growth pattern, there were 24 small mucosal type early gastric carcinomas, five superficial spreading type early gastric carcinomas, and 16 penetrating type early gastric carcinomas (four penetrating $A$ type, 12 penetrating $B$ type). $H$ pylori was found in the antral mucosa of 28 early gastric carcinomas $(62 \%)$. Activating ras gene mutations were not found. It was discovered that activating point mutations at codons 12,13 , and 61 of the Ki-, Ha-, and N-ras genes do not play a part in the development of early gastric carcinomas in white subjects, irrespective of Lauren type. Moreover, differences in biological behaviour between early carcinomas with different types of growth pattern are not related to these ras gene mutations. Finally, $H$ pylori positive and $H$ pylori negative gastric carcinomas cannot be discriminated on the basis of ras gene mutational analysis.

(Gut 1995; 37: 758-762)
\end{abstract}

Keywords: ras gene mutation, early gastric carcinomas.

The human ras proto-oncogene family includes the homologous $\mathrm{Ha}-, \mathrm{Ki}-$, and $\mathrm{N}$-ras genes, which code for closely related $21 \mathrm{kDa}$ proteins $\left(\mathrm{p} 21^{\mathrm{ras}}\right)$. These proteins, located at the inner cell membrane, can bind GDP and GTP and possess intrinsic GTP-ase activity. ${ }^{1}$ Activation of the ras genes can be due to gene amplification with enhanced expression of p $21^{\text {ras }}$ proteins. ${ }^{2}$ Activation is usually caused by point mutations at codons 12,13 , or 61 of the ras genes, however, which confer transforming properties to these proto-oncogenes. As these mutations are all localised to or near the GTP-binding domain, the intrinsic GTP-ase activity of the $21^{\text {ras }}$ proteins is nearly $100 \%$ reduced and the $\mathrm{p} 21^{\text {ras }}$ proteins persist in their biologically active, GTP-bound state. This, in turn, leads to a continuous signal transduction, even in the absence of an external stimulus. ${ }^{3}$

Point mutations in the Ki-ras gene are uniformly reported to be common in human malignancies such as lung, pancreatic, and colonic carcinoma..$^{4-6}$ In contrast, conflicting data on the frequency and type of ras gene mutations in human gastric carcinomas have been reported, varying from $0-35 \%$ of cases. ${ }^{7-14}$ Most of the previous studies on gastric carcinoma did not analyse all ras genes for the presence of point mutations and did not include early gastric carcinomas. Moreover, all but one of the previous studies did not discriminate between the intestinal and diffuse type carcinoma according to Lauren. As these two types not only differ in morphological, clinical, and epidemiological characteristics, ${ }^{15-17}$ but also differ in pathogenesis, ${ }^{18} 19$ it might well be that the genetic changes underlying both tumour types are also different. Interestingly, recent studies (both histological and serological) suggest that approximately $60 \%$ of all gastric carcinomas, irrespective of Lauren type, may be attributable to Helicobacter pylori. ${ }^{20-24}$ To date, however, no studies have been reported that have dealt with the issue as to whether or not $H$ pylori positive and $H$ pylori negative gastric carcinomas differ in molecular make up. Finally, although the prognosis of surgically treated early gastric carcinomas is generally excellent, ${ }^{25}$ its metastatic potential and postoperative five year survival rate seem to be correlated with the type of growth pattern. ${ }^{26}$ The mechanism(s) underlying these apparent differences in biological behaviour still remain(s) to be elucidated. Therefore, in view of the above, we have examined activating point mutations in the $\mathrm{Ha}-, \mathrm{Ki}-$, and $\mathrm{N}$-ras genes with the following aims: (a) to assess the prevalence and type of ras gene mutations in a series of early gastric carcinomas in white patients and (b) to 
correlate the presence of these mutations, if any, with the Lauren type, the type of growth pattern, and the $H$ pylori status.

\section{Methods}

Tissues

Forty five gastrectomy specimens from patients with early gastric carcinomas, previously classified as either intestinal- or diffuse-type according to Lauren, were retrieved from the files. The tissues had been fixed in $10 \%$ buffered formalin and processed to paraffin wax by routine methods. Early gastric carcinoma was defined according to the Japanese Society of Gastrointestinal Endoscopy. ${ }^{27}$ The tumour histology according to Lauren and the type of growth pattern according to Kodama (Fig 1) were assessed using the original paraffin wax embedded, haematoxylin and eosin stained sections. All tissue blocks of non-malignant antral mucosa were recut and stained by haematoxylin and eosin and Giemsa. Chronic atrophic gastritis, intestinal metaplasia, and $H$ pylori status were assessed using the criteria of the Sydney classification. ${ }^{28} 29 \mathrm{H}$ pylori was judged absent when both staining methods were negative for the micro-organism. All parameters were independently assessed by two of the authors $(\mathrm{MC} / \mathrm{PB})$. In rare cases of disagreement, consensus was reached after discussion.

\section{DNA isolation}

Six serial $5 \mu \mathrm{m}$ sections were cut from each paraffin wax embedded tumour block. A haematoxylin and eosin stained section was prepared to permit precise localisation of the tumour area and to estimate the proportion of tumour cells present. Then, the tumour area was selectively scraped off, thereby increasing the number of tumour cells to at least $50 \%$ of the total cell population. After collection in separate Eppendorf reaction tubes (each containing five sections), $200 \mu \mathrm{l}$ of a lysis buffer (10 mM TRIS $\mathrm{HCl}$ (pH 8.3), 1 mM EDTA, $0.2 \%$ Tween 20 , and Proteinase $\mathrm{K}(20 \mu \mathrm{g} / \mu \mathrm{l}))$ was added. After overnight incubation at
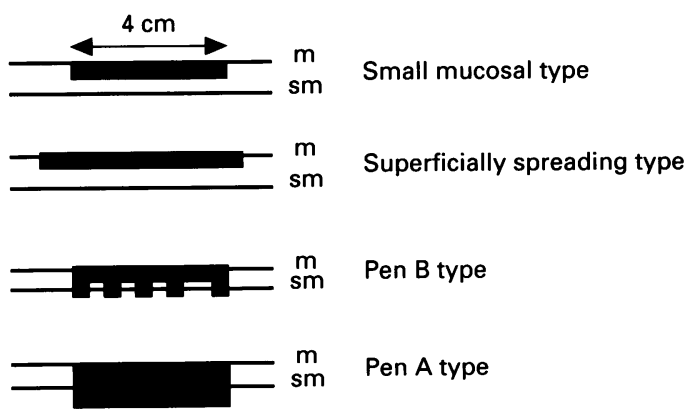

Figure 1: Types of growth pattern of early gastric carcinomas according to Kodama et al (adapted from ref 26); $m=m u \cos a, s m=s u b m u c o s a$. Small mucosal type; early gastric carcinomas $<4 \mathrm{~cm}$ with mucosal or only slight submucosal invasion. Superficially spreading type; early gastric carcinomas $>4 \mathrm{~cm}$ confined to either mucosa or submucosa. Penetrating (Pen) A type; early gastric carcinomas $<4 \mathrm{~cm}$ and growing expansively with complete destruction of the muscularis mucosae. Pen B type; early destruction of the muscularis mucosae. Pen $B$ type; early
gastric carcinomas $<4 \mathrm{~cm}$ and growing infiltratively with fenestration of the muscularis mucosae. $56^{\circ} \mathrm{C}$, the samples were heated for 10 minutes at $100^{\circ} \mathrm{C}$ to inactivate Proteinase K. After 10 minutes of centrifugation at $12000 \mathrm{rpm}$, the supernatant was removed and stored at $4^{\circ} \mathrm{C}$ for later use. Additional serial sectioning of each tumour block for other related studies showed that the tumours were still present and had not been cut out of the blocks.

PCR-RFLP analysis of $K i-12$ ras gene mutations To detect $\mathrm{Ki}-12$ ras gene mutations, a polymerase chain reaction based restriction fragment length polymorphism (PCR-RFLP) analysis was used. ${ }^{30-33}$ Briefly, this technique uses a two stage PCR amplification. In the first reaction, a Mva I (BstNI) restriction enzyme recognition site is generated in the $\mathrm{Ki}-12$ ras wild-type allele. After incubation with Mva I, the non-cleaved (mutant-enriched) DNA is again amplified with a different primer pair. The first PCR was performed in a reaction mixture containing $5 \mu \mathrm{l}$ of $10 \times \mathrm{PCR}$ buffer (35 $\mathrm{mM} \quad \mathrm{MgCl}_{2}, 150 \mathrm{mM}\left(\mathrm{NH}_{4}\right) \mathrm{SO}_{4}$, $600 \mathrm{mM}$ TRIS $\mathrm{HCl} \mathrm{pH} \mathrm{8.4),} 1 \mu \mathrm{l}$ of primers A and $B(50 \mathrm{pmol} / \mu \mathrm{l}), 2 \cdot 5 \mu \mathrm{l}$ of deoxynucleoside triphosphates mixture ( $2 \mathrm{mM}$ each), $0.2 \mu \mathrm{l}$ Taq polymerase $(5 \mathrm{U} / \mu \mathrm{l}$, Perkin-Elmer Cetus, Emmeryville, USA), $5 \mu$ l of extracted template (slide) DNA and $\mathrm{H}_{2} \mathrm{O}$ up to a final volume of $50 \mu$ l. Each mixture was overlayed with two drops of mineral oil. The PCR profile was as follows: five minutes at $96^{\circ} \mathrm{C}$ for one cycle, two minutes at $96^{\circ} \mathrm{C}$, one minute at $55^{\circ} \mathrm{C}$, one minute at $73^{\circ} \mathrm{C}$ for one cycle, followed by 23 cycles of 30 seconds at $96^{\circ} \mathrm{C}, 30$ seconds at $55^{\circ} \mathrm{C}$, one minute at $73^{\circ} \mathrm{C}$. Thereafter, Mva I digestion was performed at $37^{\circ} \mathrm{C}$ for one hour in a final reaction volume of $25.5 \mu \mathrm{l}$, containing: $12.5 \mu \mathrm{l}$ of the first PCR product, $2 \cdot 5 \mu \mathrm{l}$ of Mva I adjustment buffer, $0.5 \mu \mathrm{l}$ of Mva I (10 U/ $\mu \mathrm{l}$, Boehringer), and $10 \mu \mathrm{l} \mathrm{H}_{2} \mathrm{O}$. The second PCR was performed under similar conditions as the first PCR with minor modifications; primer B was replaced by primer C, $1 \mu \mathrm{l}$ of Mva I digested DNA served as template DNA, whereas the PCR profile consisted of five minutes at $96^{\circ} \mathrm{C}$ for one cycle, two minutes at $96^{\circ} \mathrm{C}$, one minute at $55^{\circ} \mathrm{C}$, one minute at $73^{\circ} \mathrm{C}$ for one cycle, followed by 35 cycles of 30 seconds at $96^{\circ} \mathrm{C}, 30$ seconds at $55^{\circ} \mathrm{C}$, one minute at $73^{\circ} \mathrm{C}$.

All PCR-RFLP products were tested by dot blot hybridisation to verify the presence or absence of mutations.

PCR amplification of other ras-specific sequences Amplification of $\mathrm{Ki}-13,61$, and all $\mathrm{Ha}$ and $\mathrm{N}$-ras sequences (codons $12,13,61$ ) was performed as described by Slebos et al. ${ }^{34}$

\section{Dot blot hybridisation with allele-specific} oligodeoxynucleotide probes

For each oligodeoxynucleotide (ASO) probe, one Nitran $\mathrm{N}$ membrane (Schleicher and Schuell) was cut and attached to a glass plate. One microlitre of the PCR products was spotted onto the membranes. The membranes 
Oligonucleotides for $\mathrm{Ki}-12$ ras gene mutation analysis

Sequence

Primers

A (5' amplimer)

B (3', amplimer)

C (3' amplimer)

Allele-specific oligonucleotides (ASO) $\dagger$

$\mathrm{K}-12$ wild-type

$\mathrm{K}-12$ a

$\mathrm{K}-12 \mathrm{~b}$

$\mathrm{K}-12 \mathrm{c}$

$\mathrm{K}-12 \mathrm{~d}$

$\mathrm{K}-12 \mathrm{~d}$

$\mathrm{K}-12$ f

ॠMismatched nucleotides, †mutant nucleotides.

were air dried and thereafter exposed to ultraviolet irradiation for two minutes for DNA cross linking. To analyse mutations of the $\mathrm{Ki}$-ras gene at codon 12, allele-specific ${ }^{32} \mathrm{P}$-labelled ASO probes were used as listed in the Table. For all other ras gene mutations, ASO probes were used as described by Verlaan-de Vries et al. ${ }^{35}$ All probes were purchased from Pharmacia. Before labelling, the membranes were heated at $96.8^{\circ} \mathrm{C}$ in 0.1 standard saline citrate for 10 minutes. Labelling of each probe and subsequent hybridisation procedures were performed as described by Kern et al. ${ }^{36}$ Mutations were detected by overnight autoradiography at $-70^{\circ} \mathrm{C}$.

\section{Validation of the mutational assays}

In a previous study by Slebos and Rodenhuis, ${ }^{34}$ it was shown that the conventional mutational assays - similar to those used in our study - were able to detect a 5\% subpopulation of cells containing a specific ras gene mutation among $95 \%$ of cells with the wild-type sequence $(1: 20)$. Analogous to their experiments, we validated our PCR-RFLP technique for the detection of $\mathrm{Ki}-12$ ras gene mutations by mixing DNAs of two different adenocarcinoma cell lines: GLC-A1 (wild-type sequence) and NCI-H23 (codon 12 mutation). After amplification according to our PCR-RFLP protocol, dot blot hybridisation was performed as described. The PCR-RFLP technique detected a $0.4 \%$ subpopulation of mutant cells among $99.6 \%$ wild type cells (1:250) (data not shown).

\section{Statistics}

The $\chi^{2}$ test was used for statistical analysis. A p value $<0.05$ was considered significant.

\section{Results}

Histology

There were 20 intestinal-type and 25 diffusetype early gastric carcinomas. Chronic atrophic gastritis was present in 35 gastrectomy specimens. Intestinal metaplasia was found in the surrounding mucosa of $95 \%$ (19 of 20) intestinal-type early gastric carcinomas and of $52 \%$ (13 of 25) diffuse-type early gastric carcinomas $(p<0.01)$. In the intestinal metaplasia positive cases, moderate/severe intestinal metaplasia was found in $68.4 \%$ (13 of 19$)$ of intestinal-type early gastric carcinomas and in $23.1 \%$ (three of 13 ) diffuse-type early gastric carcinomas $(\mathrm{p}<0.05) . H$ pylori was present in the antral mucosa of 14 intestinal-type (70\%) and 14 diffuse-type early gastric carcinomas $(56 \%)$ (NS).

\section{Growth pattern}

Twenty, seven early carcinomas $(60 \%)$ were confined to the mucosa and 18 (40\%) extended into the submucosa. According to growth pattern, there were 24 small mucosaltype early gastric carcinomas (all limited to the mucosa), five superficially spreading-type early gastric carcinomas (three mucosal, two submucosal), and 16 penetrating type early gastric carcinomas (four penetrating A type, 12 penetrating B type).

\section{Mutational analysis}

Positive and negative controls were included in all series of mutational assays and were run contemporaneously with the test cases to minimise the risk of false positive and false negative results. DNA from tumours previously shown to contain ras gene mutations served as positive controls. DNA from tumours known to contain only the wild-type sequence were used as negative controls. Distilled water was also used as a control in all assays. All tumours tested showed a positive hybridisation signal for the wild-type sequence. After high-stringency washing of the blots, however, activating point mutations of the ras genes were found absent in all early gastric carcinomas, irrespective of Lauren type, type of growth pattern, and $H$ pylori status (Fig 2).

\section{Discussion}

Our results show that activating point mutations at codons 12, 13, and 61 of the $\mathrm{Ki}-$, Ha-, and $\mathrm{N}$-ras genes apparently do not play a part

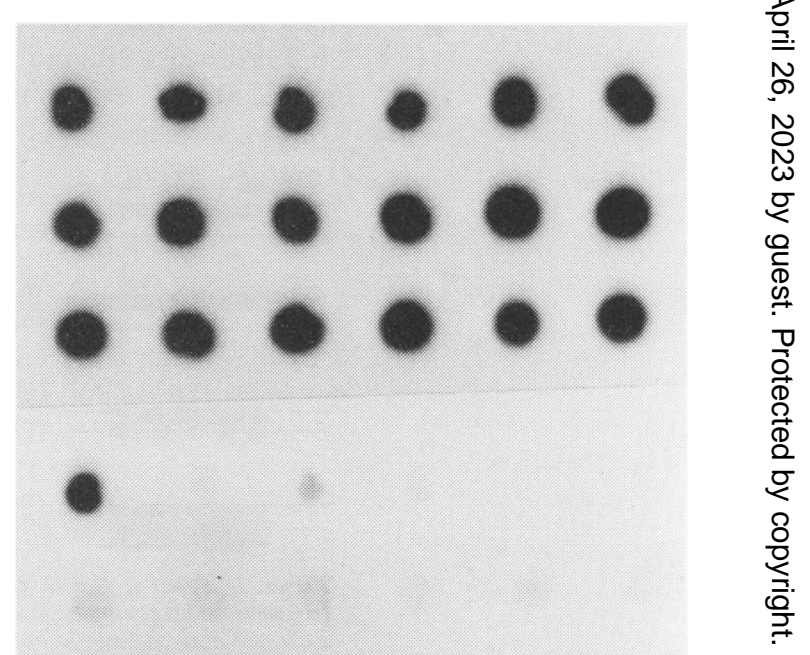

Figure 2: Dot blot hybridisation for Ki-12 ras gene mutation detection. Top: autoradiogram after non-stringent washing; bottom: same autoradiogram after high stringency washing: only the positive control shows a signal. 
in the development of gastric carcinomas of white subjects. In contrast, studies on gastric carcinomas of Asian subjects have shown that ras gene mutations can occur in up to $35 \%$ of cases. Several explanations might underlie these discrepant results. In contrast with Asian investigators, we only studied early gastric carcinomas. As early gastric carcinoma is thought to precede advanced gastric carcinoma during gastric carcinogenesis, it might well explain the disparity between our results and theirs. European-American studies on advanced gastric carcinomas, however, have also reported ras gene mutations to be very rare or even absent. ${ }^{12} 14$ Interestingly, considerable differences in ras gene mutational spectrum between non-small cell lung cancers in white and Asian subjects ${ }^{37} 38$ have been found. The contrasting findings of ras gene mutations in gastric carcinomas in white and Asian subjects might therefore also relate to differences in patient groups studied, assuming racial differences or geographical differences, or both, in carcinogenic exposure. Further evidence for this assumption is the finding that pancreatic carcinomas of European subjects show considerable geographical differences in mutational spectrum of the Ki-ras gene. ${ }^{39}$ Finally, as no mutations at all were found in our study, technical caveats should be considered as well. It is well known that DNA isolated from formalin fixed tissues is usually partially degraded into smaller fragments. The extent of degradation is influenced by many factors, for example, the time between removal of the tissue and fixation, the duration of the fixation step, and the type of fixative used. The average length of DNA extracted from (formalin) fixed tissues, however, is usually in the range of 100-500 nucleotides. ${ }^{40}$ As only small DNA fragments need to be amplified for the detection of point mutations in the ras genes, the effect of DNA degradation should be regarded as of minor importance only for the detection of ras gene mutations, in contrast with, for example, mutation analysis of the p53 gene. Moreover, all cases tested positive for the wild-type sequence of the ras genes. As such, the positive wild-type signals served as internal controls for DNA extraction, amplification, and hybridisation procedures in each case. Therefore, in view of the above and in view of the sensitivity of our assays in combination with the fact that the tumour cells constituted at least $50 \%$ of the total cell population per case, we strongly feel that the absence of ras gene mutations in our series is genuine and not the result of technical flaws.

Immunohistochemical studies on $\mathrm{p} 21^{\text {ras }}$ expression in gastric carcinomas have reported increased expression of $\mathrm{p} 21^{\text {ras }}$ proteins, especially in intestinal-type carcinomas compared with diffuse-type carcinomas. ${ }^{41-45}$ Moreover, it was found that the normal mucosa surrounding diffuse-type tumours, but not surrounding intestinal-type tumours, showed increased expression of $\mathrm{p} 21^{\text {ras }}$ proteins. Interestingly, intestinal metaplasia and dysplasia, surrounding intestinal-type carcinomas, also showed increased expression of $\mathrm{p} 21^{\text {ras }}$ proteins. ${ }^{43}$ It was suggested that these findings supported a role for the ras genes in gastric carcinogenesis and supported the concept of a different carcinogenic pathway of both Lauren types. These suggestions are in contrast with our own findings. Various explanations may account for this apparent discrepancy. Firstly, it should be noted that increased $\mathrm{p} 21^{\text {ras }}$ protein expression in tumours does not necessarily indicate that the levels of the $\mathrm{p} 21^{\text {ras }}$ protein(s) have transforming capability. It is noteworthy that immunohistochemical studies especially can be classified as semi-quantitative at best. Secondly, increased p $21^{\text {ras }}$ expression is not necessarily synonymous with malignant phenotype, as it has also been seen in regenerating rat liver and in regenerating epithelium adjacent to peptic ulceration. ${ }^{4246}$ Presumably, a moderate increase in ras gene expression is therefore related to active cell proliferation rather than to malignant phenotype. Thirdly, although overexpression of wild-type p21 $1^{\text {ras }}$ has been implicated in malignant transformation, 24748 this mechanism is generally considered to be a rare event in tumorigenesis. Fourthly, inherent pitfalls of most p2 $1^{\text {ras }}$ antibodies hamper a correct interpretation of immunohistochemical studies. ${ }^{49}$ Therefore, in view of the above and in view of the absence of activating ras gene mutations in our series, we feel that ras gene abnormalities in all probability do not contribute to gastric carcinogenesis and in all probability do not contribute to the concept of a different pathogenesis of both Lauren types.

To date, the role of $H$ pylori in gastric carcinogenesis is a topic of great interest. Whereas many studies have been published that suggest a role for $H$ pylori in this process, no studies so far have reported on the difference in molecular make up, if any, between $H$ pylori positive and $H$ pylori negative gastric carcinomas. A pitfall of retrospective studies in classifying carcinomas into $H$ pylori positive and $H$ pylori negative cases is that extensive intestinal metaplasia formation, particularly in the course of the carcinogenic process of intestinal-type carcinomas may have led to the disappearance of the micro-organism in the stomach, resulting in an underestimation of its prevalence. Moreover, previous use of antibiotics may also have confounded results. Nevertheless, as ras gene mutations were completely absent in our series, it may be assumed that $H$ pylori positive and $H$ pylori negative gastric carcinomas cannot be discriminated on the basis of ras gene mutational analysis.

Despite the excellent prognosis of surgically treated early gastric carcinomas compared with advanced gastric carcinomas, the metastatic potential and postoperative five year survival rate of early gastric carcinomas seem to be correlated with the type of growth pattern. In particular, the penetrating A type, in contrast with the other growth types, has been reported to have a high propensity for blood vessel invasion and lymph node metastasis and to have the worst prognosis after surgery because of early postoperative hepatic metastasis. ${ }^{26}$ In a related study we showed that this apparent 
difference in clinical or biological behaviour, or both, could not be explained on the basis of a difference in nuclear $\mathrm{p} 53$ protein accumulation. ${ }^{50}$ This study shows that ras gene mutations do not underlie these clinical findings either.

In conclusion, activating point mutations at codons 12, 13, and 61 of the $\mathrm{Ha}-, \mathrm{Ki}-$, and $\mathrm{N}$-ras genes do not play a part in the development of (early) gastric carcinomas of white subjects irrespective of Lauren type. Moreover, these ras gene mutations do not underlie the differences in clinical or biological behaviour, or both, of early gastric carcinomas with different types of growth pattern. Finally, $H$ pylori positive and $H$ pylori negative gastric carcinomas cannot be discriminated by ras gene mutational analysis.

B Top is supported by grant NKI-9108 from the Dutch Cancer Society.

1 Bos JL. The ras gene family and human carcinogenesis. Mutat Res 1988; 195: 255-71.

2 Pulciani S, Santos E, Long LK, Sorrentino V, Barbacid M. Ras gene amplification and malignant transformation. Mol Ras gene amplification and

3 Sigal IS. The ras oncogene: a structure and some function. Nature 1988; 332: 485-6.

4 Slebos RJC, Kibbelaar RE, Dalesio O, Kooistra J, Stam J, Meijer CJLM, et al. Kirsten-ras oncogene activation as a prognostic marker in adenocarcinoma of the lung. $N$ Engl f Med 1990; 323: 561-5.

5 Almoguera C, Shibata D, Forrester K, Martin J, Arnheim N, Perucho M. Most human carcinomas of the exocrine pancreas contain mutant c-K-ras genes. Cell 1988; 53: 549-54.

6 Bos IL, Fearon ER, Hamilton SR, Verlaan-de Vries M, van Boom JH, van der Eb AJ, et al. Prevalence of ras gene 293-7.

7 Fujida K, Ohuchi N, Yao T, Okumura M, Fukushima Y, Kanakura $\mathrm{Y}$, et al. Frequent overexpression, but not activation by point mutation of ras genes in primary human gastric cancers. Gastroenterology 1987; 93: 1339-45.

8 Deng G, Liu X, Wang J. Correlation of mutations of oncogene c-Ha-ras at codon 12 with metastases and survival of gastric cancer patients. Oncogene Res 1991; 6: 33-8.

9 Kihana T, Tsuda H, Hirota T, Shimosato Y, Sakamoto H, Terada $\mathrm{M}$, et al. Point mutations of c-Ki-ras oncogene in gastric adenoma and adenocarcinoma with tubular differgastric adenoma and adenocarcinoma with tubul

10 Lin SY, Chen PH, Wang CK, Liu JD, Siauw CP, Chen YJ, et al. Mutation analysis of $\mathrm{K}$-ras oncogenes in gastroenterologic cancers by the amplified created restriction sites method. Am $\mathcal{f}$ Clin Pathol 1993; 100: 686-9.

11 Jiang W, Kahn SM, Guillem JG, Lu SH, Weinstein IB. Rapid detection of ras oncogenes in human tumours: applications to colon, oesophageal and gastric cancer. Oncogene 1989; 4: 923-8.

12 Victor T, Du Toit R, Jordaan AM, Bester AJ, van Helden PD. No evidence for point mutations in codons 12,13 , and 61 of the ras gene in a high incidence area for esophageal

13 Nagata $Y$, Abe $M$, Kobayashi $K$, Yoshida $K$, Ishibashi $T$, Naoe $T$, et al. Glycine to aspartic acid mutations at codon 13 of the c-Ki-ras gene in human gastrointestinal cancers. Cancer Res 1990; 50: 480-2.

14 Nanus DM, Kelsen DP, Mentle IR, Altorki N, Albino AP. Infrequent point mutations of ras oncogenes in gastric cancers. Gastroenterology 1990; 98: 955-60.

15 Lauren $P$. The two histological main types of gastric carcinoma: diffuse and so-called intestinal-type carcinoma. Acta Pathol Microbiol Scand 1965; 64: 31-49.

16 Davessar K, Pezzulo JC, Kessimian N, Hale JH, Jauregui HO. Gastric adenocarcinoma: prognostic significance of s. Geral pathologic parameters and histologic classification. several pathologic parameters a

17 Munoz N, Correa P, Cuello C, Duque E. Histologic types of gastric carcinoma in high- and low-risk areas. Int $\mathcal{f}$ Cancer 1968; 3: 809-18.

18 Correa P. Precursors of gastric and esophageal cancer. Cancer 1982; 50: 2554-65.

19 Correa P. A human model of gastric carcinogenesis. Cancer Res 1988; 48: 1319-26.

20 Sipponen P, Kosunen TU, Valle J, Riihela M, Seppala K. Helicobacter pylori infection and chronic gastritis in gastric cancer. F Clin Pathol 1992; 45: 319-23.

21 Craanen ME, Blok P, Dekker W, Tytgat GNJ. Helicobacter pylori and early gastric cancer. Gut 1994; 35: 1372-4.
22 Parsonnet J, Friedman GD, Vandersteen JP, Chang Y, Vogelman $\mathrm{JH}$, Orentreich $\mathrm{N}$, et al. Helicobacter pylori infection and the risk of gastric carcinoma. $N$ Engl $\mathscr{f}$ Med 1991; 325: 1127-31.

23 Nomura A, Stemmermann GN, Chyou P-H, Kato I, PerezPerez GI, Blaser MJ. Helicobacter pylori infection and gastric carcinoma among Japanese Americans. $N$ Engl $f$ Med 1991; 325: 1132-6.

24 Forman D, Webb PM. H pylori and gastric cancer: the significance of the problem. In: Hunt RH, Tytgat GNJ,
eds. Helicobacter pylori. Basic mechanisms to clinical cure. eds. Helicobacter pylori. Basic mechanisms to
Dordrecht: Kluwer Academic, 1994: 461-8.

25 Craanen ME, Dekker W, Ferwerda J, Blok P, Tytgat GNJ. Early gastric cancer: a clinicopathologic study. $\mathcal{F}$ Clin Gastroenterol 1991; 13: 274-83.

26 Kodama Y, Inokuchi K, Soejima K, Matsusaka $T$, Okamura T. Growth patterns and prognosis in early gastric carcinoma. Cancer 1983; 51: 320-6.

27 Murakami T. Pathomorphological diagnosis. Definition and gross classification of early gastric cancer. In: Murakami T, ed. Early gastric cancer. Gann monograph on cancer research. Vol 11 . Tokyo: University of Tokyo Press, 1971: 53-5.

28 Misiewicz JJ. The Sydney system: a new classification of gastritis. Introduction. 7 Gastroenterol Hepatol 1991; 6: 207-8.

29 Price AB. The Sydney system: histological division. f Gastroenterol Hepatol 1991; 6: 209-22.

30 Kahn SM, Jiang W, Culbertson TA, Weinstein IB, Williams GM, Tomita N, et al. Rapid and sensitive non-radioactive detection of mutant K-ras genes via 'enriched' PCR amplification. Oncogene 1991; 6: 1079-83.

31 Levi S, Urbano-Ispizua A, Gill R, Thornas DM, Gilbertson $\mathrm{J}$, Foster $\mathrm{C}$, et al. Multiple K-ras codon 12 mutations in cholangiocarcinomas demonstrated with a sensitive polymerase chain reaction technique. Cancer Res 1991; 51: merase chain

32 van Mansveld ADM, Bos JL. PCR based approaches for detection of mutated ras genes. PCR Methods and Applications 1992; 1: 211-6.

33 Hruban RH, van Mansfeld ADM, Offerhaus GJA, van Weering DHJ, Allison DC, Goodman SN, et al. K-ras oncogene activation in adenocarcinoma of the human pancreas. Am F Pathol 1993; 143: 545-54.

34 Slebos RJC, Boerrigter L, Evers SG, Wisman P, Mooi WJ, Rodenhuis $S$. A rapid and simple procedure for the routine detection of ras point mutations in formalin-fixed, paraffin-embedded tissues. Diagnostic Molecular Pathology paraffin-embedded

35 Verlaan-de Vries $M$, Bogaard ME, van den Elst $H$, van Boom JH, van der Eb AJ, Bos JL. A dot-blot screening procedure for mutated ras oncogenes using synthetic oligodeoxynucleotides. Gene 1986; 50: 313-20.

36 Kern JA, Slebos RJC, Top B, Rodenhuis S, Lager D, Robinson RA, et al. C-erbB-2 expression and codon $12 \mathrm{~K}$ ras mutations both predict shortened survival for patients with pulmonary adenocarcinomas. F Clin Invest 1994; 93: 516-20.

37 Rodenhuis S, Slebos RJC. Clinical significance of ras oncogene activation in human lung cancer. Cancer Res 1992; 52: 2665-9s.

38 Suzuki Y, Orita M, Shiraishi M, Hayashi K, Sekiya N. Detection of ras gene mutation in human lung cancers by single-strand conformation polymorphism analysis of polymerase chain reaction products. Oncogene 1990; 5: $1037-43$

39 Scarpa A, Capelli P, Villanueva A, Zamboni G, Lluis F, Accolla $\mathrm{R}$, et al. Pancreatic cancer in Europe: Ki-ras gene
mutation pattern shows geographical differences. Int $\mathcal{F}$ Cancer 1994; 57: 167-71.

40 Goelz SE, Hamilton SR, Vogelstein B. Purification of DNA from formaldehyde fixed and paraffin embedded human tissue. Biochem Biophys Res Commun 1985; 130: 118-26.

41 Yoshida K, Hamatani K, Koide H, Abe Y, Ikeda H, Tsuchiyama $\mathrm{H}$, et al. Analysis of ras gene expression in
stomach cancer by anti-ras p21 monoclonal antibodies. stomach cancer by anti-ras p21 mo

42 Yoshida K, Hamatani K, Koide H, Ikeda H, Nakamura N, Akiyama $\mathrm{M}$, et al. Preparation of anti-ras $\mathrm{M}_{\mathrm{r}} 21000$ protein monoclonal antibodies and immunohistochemical analyses on expression of ras genes in human stomach and thyroid cancers. Cancer Res 1988; 48: 5503-9.

43 Czerniak B, Herz F, Gorczyca W, Koss L. Expression of ras oncogene p 21 protein in early gastric carcinoma and adjacent gastric epithelia. Cancer 1989; 64: 1467-73.

44 Tahara E, Yasui W, Taniyama K, Ochiai A, Yamamoto T, Nakajo $S$, et al. Ha-ras oncogene product in human gastric carcinoma: correlation with invasiveness, metastasis or carcinoma: correlation with invasiveness, me

prognosis. Fpn 7 Cancer Res 1986 ; 77: $517-22$.
45 Wright PA, Williams GT. Molecular biology and gastric carcinoma. Gut 1993; 34: 145-7.

46 Goyette M, Petropoulos CJ, Shank PR, Fausto N. Expression of a cellular oncogene during liver regeneration. Science 1983; 219: 510-2.

47 Alitalo K. Amplification of cellular oncogenes in cancer cells. Med Biol 1984; 62: 304-17.

48 Varmus HE. The molecular genetics of cellular oncogenes. Annu Rev Genet 1984; 18: 553-61.

49 Rodenhuis S. Ras and human tumors. Semin Cancer Biol 1992; 3: 241-7.

50 Craanen ME, Blok P, Dekker W, Offerhaus GJA, Tytgat GNJ. Chronology of $\mathrm{p} 53$ protein accumulation in gastric carcinogenesis. Gut 1995; 36: 848-52. 